\title{
Nitrous oxide emissions from a peatbog after 13 years of experimental nitrogen deposition
}

\author{
Sarah R. Leeson, Peter E. Levy, Netty van Dijk, Julia Drewer, Sophie Robinson, Matthew R. Jones, John Kentisbeer, \\ Ian Washbourne, Mark A. Sutton, and Lucy J. Sheppard
}

Centre of Ecology and Hydrology, Edinburgh, UK

Correspondence: Peter E. Levy (plevy@ceh.ac.uk) and Sarah R. Leeson (sarle@ceh.ac.uk)

Received: 1 March 2016 - Discussion started: 24 March 2016

Revised: 13 October 2016 - Accepted: 25 October 2016 - Published: 21 December 2017

\begin{abstract}
Nitrogen deposition was experimentally increased on a Scottish peatbog over a period of 13 years (2002-2015). Nitrogen was applied in three forms, $\mathrm{NH}_{3}$ gas, $\mathrm{NH}_{4} \mathrm{Cl}$ solution, and $\mathrm{NaNO}_{3}$ solution, at rates ranging from 8 (ambient) to $64 \mathrm{~kg} \mathrm{Nha}^{-1} \mathrm{yr}^{-1}$, and higher near the $\mathrm{NH}_{3}$ fumigation source. An automated system was used to apply the nitrogen, such that the deposition was realistic in terms of rates and high frequency of deposition events. We measured the response of nitrous oxide $\left(\mathrm{N}_{2} \mathrm{O}\right)$ flux to the increased nitrogen input. Prior expectations, based on the IPCC default emission factor, were that $1 \%$ of the added nitrogen would be emitted as $\mathrm{N}_{2} \mathrm{O}$. In the plots treated with $\mathrm{NH}_{4}^{+}$and $\mathrm{NO}_{3}^{-}$solution, no response was seen, and there was a tendency for $\mathrm{N}_{2} \mathrm{O}$ fluxes to be reduced by additional nitrogen, though this was not significant. Areas subjected to high $\mathrm{NH}_{3}$ emitted more $\mathrm{N}_{2} \mathrm{O}$ than expected, up to $8.5 \%$ of the added nitrogen. Differences in the response are related to the impact of the nitrogen treatments on the vegetation. In the $\mathrm{NH}_{4}^{+}$and $\mathrm{NO}_{3}^{-}$treatments, all the additional nitrogen is effectively immobilised in the vegetation and top $10 \mathrm{~cm}$ of peat. In the $\mathrm{NH}_{3}$ treatment, much of the vegetation was killed off by high doses of $\mathrm{NH}_{3}$, and the nitrogen was presumably more available to denitrifying bacteria. The design of the wet and dry experimental treatments meant that they differed in statistical power, and we are less likely to detect an effect of the $\mathrm{NH}_{4}^{+}$and $\mathrm{NO}_{3}^{-}$treatments, though they avoid issues of pseudo-replication.
\end{abstract}

\section{Introduction}

Since the industrial revolution, peatlands have been subject to increased deposition of anthropogenic nitrogen $(\mathrm{N})$, as a result of fossil fuel burning and agricultural use (Fowler et al., 2005). The overall consequences of enhanced $\mathrm{N}$ deposition in ombrotrophic peatbogs are poorly understood, but bogs are likely to be sensitive to enhanced $\mathrm{N}$ inputs, because they are adapted to conditions of very low $\mathrm{N}$ availability (Bobbink et al., 1998). When $\mathrm{N}$ deposition exceeds plant demand, the additional $\mathrm{N}$ may be used by soil microbes, and can result in the production of the greenhouse gas nitrous oxide $\left(\mathrm{N}_{2} \mathrm{O}\right)$ via nitrification and denitrification (Regina et al., 1996; Bobbink et al., 1998; Silvan et al., 2005). Of the total N applied to agricultural land and arising from livestock waste which is subsequently deposited on semi-natural land, it estimated that $1 \%$ is re-emitted as $\mathrm{N}_{2} \mathrm{O}$ (De Klein, 2006). This so-called "indirect" emission of $\mathrm{N}_{2} \mathrm{O}$ is a large, but uncertain, term in the national inventory of greenhouse gas emissions. There have been relatively few experimental attempts to determine these emissions on peatbogs, and most information comes from Fenno-Scandinavian bogs (Regina et al., 1998; Nykanen et al., 2002; Lund et al., 2009).

$\mathrm{N}$ deposition may lead to changes to peatbog ecosystems which influence the emission of $\mathrm{N}_{2} \mathrm{O}$ in complex ways, particularly via soil chemistry and vegetation composition (Simek and Cooper, 2002; Juutinen et al., 2010). For example, $\mathrm{N}$ deposition may affect soil $\mathrm{pH}$, which affects the composition of the microbial community (Nicol et al., 2008), and affects the relative prevalence of the biochemical pathways by which denitrification produces $\mathrm{N}_{2}$ or $\mathrm{N}_{2} \mathrm{O}$ (Simek and Cooper, 2002). Sphagnum mosses can immobilise a significant proportion of the incoming $\mathrm{N}$ deposition (Curtis et al., 
2005). If sphagnum cover is reduced as a result of $\mathrm{N}$ deposition (Bobbink et al., 1998), more $\mathrm{N}$ may become available to denitrifying microbes, and result in greater emissions of $\mathrm{N}_{2} \mathrm{O}$ (Lamers et al., 2000). The effects may also depend on the form of deposited $\mathrm{N}$, whether reduced $\mathrm{N}\left(\mathrm{NH}_{x}\right)$ coming predominantly from animal waste, or oxidised $\mathrm{N}\left(\mathrm{NO}_{x}\right)$ coming from energy combustion, and whether deposited as a gas $\left(\mathrm{NH}_{3}\right)$ or in rainfall $\left(\mathrm{NH}_{4}^{+}\right.$or $\left.\mathrm{NO}_{3}^{-}\right)$.

This paper reports measurements of $\mathrm{N}_{2} \mathrm{O}$ emissions, as part of a long-term experiment in which additional $\mathrm{N}$ has been deposited on a peatbog in central Scotland, for over 13 years, in three different forms $\left(\right.$ as $\mathrm{NH}_{3}$ gas, as $\mathrm{NH}_{4}^{+}$solution or $\mathrm{NO}_{3}^{-}$solution). The automated experiment was designed to provide realistic $\mathrm{N}$ deposition, in terms of doses, frequency ( $>100$ spray events $\mathrm{yr}^{-1}$ ), and exposure concentrations, reflecting the pollution climate experienced in the UK. Ambient $\mathrm{N}$ inputs at the site are low, so that the responses should be representative of the more pristine northern European peatbogs. Previous results from the experiment have demonstrated that high doses of $\mathrm{NH}_{3}$ reduces the cover of several plant species, but that the effects of $\mathrm{NH}_{4}^{+}$and $\mathrm{NO}_{3}^{-}$ on vegetation composition and cover are not large (Sheppard et al., 2008, 2011, 2014). Here, we examine the effects of the dose and form of $\mathrm{N}$ deposition on emissions of $\mathrm{N}_{2} \mathrm{O}$. Preliminary data on $\mathrm{N}_{2} \mathrm{O}$ fluxes were reported by Sheppard et al. (2013), showing an increase with $\mathrm{NH}_{3}$, but no effect of $\mathrm{NH}_{4}^{+}$ and $\mathrm{NO}_{3}^{-}$. Here, we analyse an additional 5 years of data collected at a wider range of locations, and with further time for any treatment effects to accumulate. The aims were to investigate (i) the extent to which $\mathrm{N}_{2} \mathrm{O}$ emissions are stimulated by $\mathrm{N}$ deposition, and whether the $1 \%$ emission factor used in IPCC inventories is accurate, (ii) whether the form of $\mathrm{N}$ deposition is important, and (iii) whether other changes induced by $\mathrm{N}$ deposition (e.g. on soil chemistry or vegetation) have an indirect effect on $\mathrm{N}_{2} \mathrm{O}$ emissions.

\section{Materials and methods}

\subsection{Field site}

Whim bog in the Scottish Borders $\left(3^{\circ} 16^{\prime} \mathrm{W}, 55^{\circ} 46^{\prime} \mathrm{N}\right)$ represents a transition between a lowland raised bog and blanket bog, on 3-6 $\mathrm{m}$ of deep peat. Mean temperatures of the air and soil (at $10 \mathrm{~cm}$ depth) were 8.6 and $7.7^{\circ} \mathrm{C}$ respectively (2003-2009 means). The annual rainfall was $1092 \mathrm{~mm}$ (734$1462 \mathrm{~mm}$ range). On average, the water table was $10 \mathrm{~cm}$ below the surface of the peat in the hollows, i.e. relatively wet for most of the year. Hummocks were typically $20 \mathrm{~cm}$ higher than the hollows. The peat was very acidic, with $\mathrm{pH} 3.4$ (3.27-3.91 in water). The vegetation was classified as a Calluna vulgaris-Eriophorum vaginatum blanket mire community (M19 in the UK National Vegetation Classification, Rodwell, 1998). Replicate plots were highly variable and dominated by unmanaged Calluna of variable age and stature oc- curring as mosaics containing Calluna vulgaris and Sphagnum capillifolium hummocks and hollows containing $S$. fallax and S. papillosum. Other common species included Erica tetralix and the mosses Hypnum jutlandicum and Pleurozium schreberi.

\subsection{Experimental Treatments}

Nitrogen was applied to the site using two different treatment systems, for dry deposition of $\mathrm{NH}_{3}$ gas, and wet deposition of $\mathrm{NH}_{4}^{+}$and $\mathrm{NO}_{3}^{-}$in solution. Treatments commenced in June 2002 and continued all year round, except when temperatures were near freezing.

$\mathrm{NH}_{3}$ deposition was manipulated using a free-air release system (Leith et al., 2004). $\mathrm{NH}_{3}$ was supplied from a cylinder of pure liquid $\mathrm{NH}_{3}$, diluted with ambient air and released from a perforated $10 \mathrm{~m}$ long pipe, $1 \mathrm{~m}$ off the ground. $\mathrm{NH}_{3}$ was released only when the wind direction was in the southwest, between 180 and $215^{\circ}$, temperatures exceeded freezing, and wind speed exceeded $2.5 \mathrm{~m} \mathrm{~s}^{-1}$. This produced a sector downwind wherein $\mathrm{NH}_{3}$ decreased with distance from the fumigation source. $\mathrm{NH}_{3}$ concentrations were measured $0.1 \mathrm{~m}$ above the vegetation using passive ALPHA samplers (Tang et al., 2001) at 8, 12, 16, 20, 24, 32, 48, and $60 \mathrm{~m}$ from the source along the transect. A detailed profile was measured to capture the concentration gradients both vertically and horizontally (Leith et al., 2004). Ammonia deposition was calculated from the concentration measurements, using the method of Cape et al. (2008). The deposition at these locations was interpolated using ordinary kriging, as shown in Fig. 1, assuming the deposition velocity was spatially homogeneous.

Wet deposition of $\mathrm{NH}_{4}^{+}$and $\mathrm{NO}_{3}^{-}$was experimentally increased in a number of replicated plots in a randomised block design, using a water sprayer system (Sheppard et al., 2004). Concentrated solutions of either $\mathrm{NH}_{4} \mathrm{Cl}$ or $\mathrm{NaNO}_{3}$ were diluted in rainwater and transferred to each plot via $100 \mathrm{~m}$ lengths of $16 \mathrm{~mm}$ pipe. Each pipe terminated in a central sprayer with a $360^{\circ}$ spinning disc that distributed the solution uniformly over the $12.8 \mathrm{~m}^{2}$ plot. The volume of solution applied to each plot was monitored using a water meter on each supply line. Three treatment levels were applied, aiming to provide total $\mathrm{N}$ deposition rates of 16,32 , and $64 \mathrm{~kg} \mathrm{Nha}^{-1} \mathrm{yr}^{-1}$, in addition to a control treatment which only received ambient $\mathrm{N}$ deposition $\left(8 \mathrm{~kg} \mathrm{Nha}^{-1} \mathrm{yr}^{-1}\right)$. The three treatment levels were achieved by applying either $\mathrm{NH}_{4} \mathrm{Cl}$ or $\mathrm{NaNO}_{3}$ solution at concentrations of $0.57,1.71$, or $4.0 \mathrm{mM}$. Wet treatments increased precipitation amounts by ca. $10 \%$. Control plots receive the additional rainwater without any additional nitrogen. There were four blocks, with one treatment level in each, to give a total of 28 plots. The sprayer system was automatically triggered every $15 \mathrm{~min}$ (so long as there was sufficient rainwater in the collection tank) air temperature was above $0^{\circ} \mathrm{C}$, and wind speed was above $5 \mathrm{~m} \mathrm{~s}^{-1}$. 


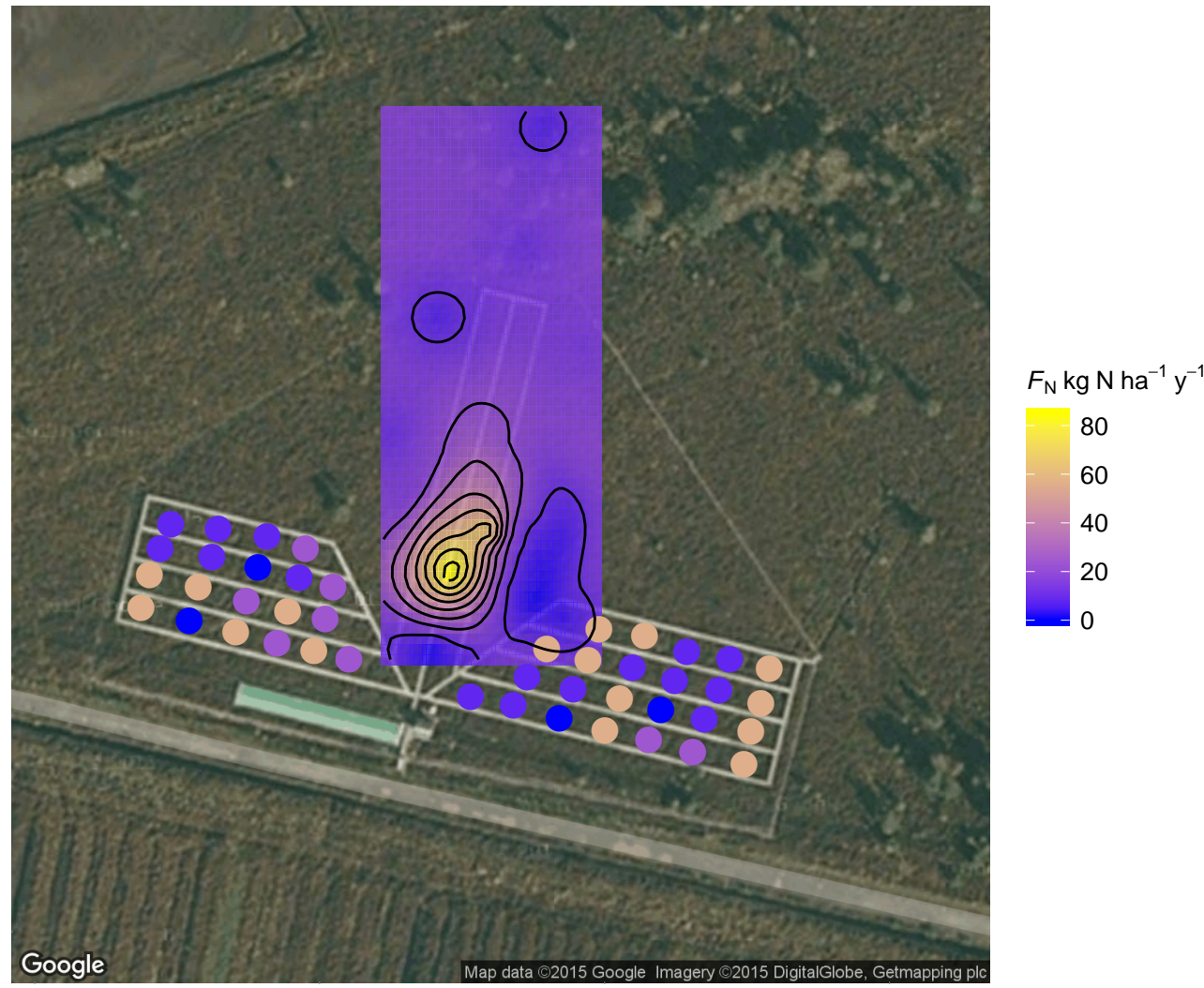

Figure 1. Spatial distribution of $\mathrm{N}$ deposition in the Whim experiment. The ammonia release system was located at the centre of the boardwalk structure in the middle of the image. Ammonia deposition was calculated from concentration measurements downwind of the ammonia source using the method of Cape et al. (2008), and interpolated across the central rectangular area of the image using ordinary kriging. In the wet deposition plots (circles in the lower part of the image), the nitrogen solution applied was sprayed evenly across the whole $12.8 \mathrm{~m}^{2}$ plot. North is at the top of the image.

This produced a realistic pattern of high frequency, extensive nitrogen deposition, with ca. 120 applications per year.

Soil water samples were extracted from dipwells in all plots at the same time as gas flux measurements were made. Concentrations of soil water $\mathrm{NH}_{4}^{+}$and $\mathrm{NO}_{3}^{-}$were measured by ion chromatography following filtration. The detection limits were 0.014 and $0.062 \mathrm{mg} \mathrm{L}^{-1}$ for $\mathrm{NH}_{4}^{+}-\mathrm{N}$ and $\mathrm{NO}_{3}^{-}$$\mathrm{N}$, respectively. The percent cover of each vegetation species was recorded within each chamber location every few years.

\subsection{Greenhouse gas exchange}

Nitrous oxide fluxes were measured by the static chamber method (Hutchinson and Mosier, 1981), typically on a monthly basis. Cylindrical PVC collars $(38 \mathrm{~cm}$ in diameter and typically $25 \mathrm{~cm}$ high) were inserted into the peat within each plot.

On each sampling occasion, a lid was sealed on top, and left in place for $30-40 \mathrm{~min}$. Four $20 \mathrm{~mL}$ samples were removed by syringe through a 3-way tap or rubber septum, stored in vials or Tedlar bags, and analysed on a gas chromatograph (5890 series II, Hewlett Packard), together with replicates of three or four standard gases with known concentrations. For each sequence of gas samples from a chamber, the flux was calculated as:

$F=\frac{\mathrm{d} C}{\mathrm{~d} t_{0}} \cdot \frac{\rho V}{A}$,

where $F$ is gas flux from the soil $\left(\mu \mathrm{mol} \mathrm{m}{ }^{-2} \mathrm{~s}^{-1}\right), \mathrm{d} C / \mathrm{d} t_{0}$ is the initial rate of change in concentration with time in $\mu \mathrm{mol} \mathrm{mol}^{-1} \mathrm{~s}^{-1}, \rho$ is the density of air in $\mathrm{mol} \mathrm{m}^{-3}, V$ is the volume of the chamber in $\mathrm{m}^{3}$, and $A$ is the ground area enclosed by the chamber in $\mathrm{m}^{2}$.

The parameter $\mathrm{d} C / \mathrm{d} t_{0}$ was calculated using linear and non-linear asymptotic regression methods (Levy et al., 2011). Using a mixture of goodness-of-fit statistics and visual inspection, the regression method that provided the best fit for the time series of concentration was chosen for each individual measurement. With this method of flux calculation, any non-linearity should be accounted for as far as possible. However, the time resolution (approximately $10 \mathrm{~min}$ ) limits the detectable degree of non-linearity in the initial concentration change, so there remains some potential for underestimation of fluxes (Cowan et al., 2014a). 


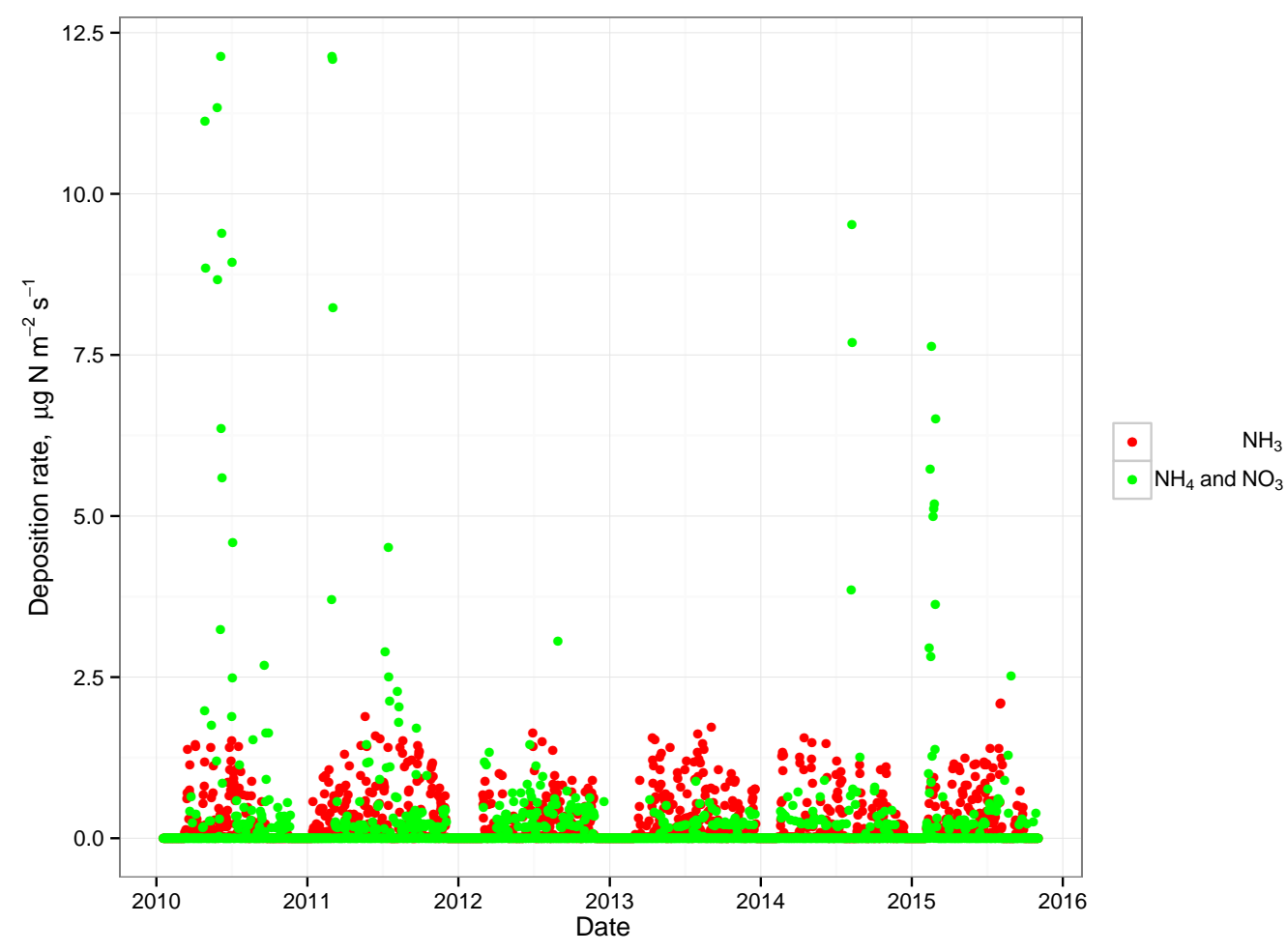

Figure 2. Daily mean nitrogen deposition rates in the $\mathrm{NH}_{4}^{+}$and $\mathrm{NO}_{3}^{-}$treatments and at $16 \mathrm{~m}$ downwind on the $\mathrm{NH}_{3}$ transect. $\mathrm{NH}_{4}^{+}$and $\mathrm{NO}_{3}^{-}$ deposition was calculated from the duration of spraying events each day, multiplied by the $\mathrm{NH}_{4}^{+}$and $\mathrm{NO}_{3}^{-}$concentration in the solution, and accounting for the area covered by the spray. $\mathrm{NH}_{3}$ deposition was calculated from the duration of fumigation events each day, measurements of $\mathrm{NH}_{3}$ concentration, and meteorological data, using the method of Cape et al. (2008).

\subsection{Statistical analysis}

The data were first analysed using a linear mixedeffects model (Pinheiro and Bates, 2006). There were 729 flux measurements in total, after removing four outlying measurements above $10 \mathrm{nmol} \mathrm{m}^{-2} \mathrm{~s}^{-1}$ and two below $-2 \mathrm{nmol} \mathrm{m}{ }^{-2} \mathrm{~s}^{-1}$. We fitted fixed-effect terms for soil temperature, $T_{\text {soil }}$, water table height, $z_{\text {water }}$ (negative values indicate depth below the surface), ammonia- $\mathrm{N}$ deposition rate, $F_{\mathrm{N}-\mathrm{NH}_{3}}$, ammonium-N deposition rate, $F_{\mathrm{N}-\mathrm{NH}_{4}}$, and nitrate$\mathrm{N}$ deposition rate, $F_{\mathrm{N}-\mathrm{NO}_{3}}$, and random-effect terms with a design matrix $\mathrm{Z}_{\mathrm{i}, \mathrm{j}}$ to account for the repeated measures on each chamber location, $j$, nested within each experimental block, $i$ :

$$
\begin{aligned}
F_{\mathrm{N}_{2} \mathrm{O}, \mathrm{ij}} & =\beta_{0}+\beta_{1} \cdot T_{\mathrm{soil}, \mathrm{ij}}+\beta_{2} \cdot z_{\mathrm{water}, \mathrm{ij}}+\beta_{3} \cdot F_{\mathrm{NH}_{3}, \mathrm{ij}} \\
& +\beta_{4} \cdot F_{\mathrm{NH}_{4}, \mathrm{ij}}+\beta_{5} \cdot F_{\mathrm{NO}_{3}, \mathrm{ij}}+b_{i} \cdot \mathrm{Z}_{\mathrm{i}, \mathrm{j}} \\
& +b_{i j} \cdot \mathrm{Z}_{\mathrm{ij}}+\epsilon_{i j} \\
& b_{i} \sim N\left(0, \sigma_{1}^{2}\right) b_{i j} \sim N\left(0, \sigma_{2}^{2}\right) \epsilon_{i j} \sim N\left(0, \sigma_{3}^{2}\right) .
\end{aligned}
$$

The data were also analysed using a general additive mixed-effects model (Wood, 2006), with the same fixed- and random effect terms, but allowing for non-linearity in the fixed-effect responses. To analyse the relationship between
$\mathrm{N}_{2} \mathrm{O}$ flux and vegetation species composition, we used a multivariate approach, partial least squares regression (PLS, Mevik and Wehrens, 2007). The approach is an extension of principal components analysis (PCA), but whereas PCA focuses on the variance in a matrix of variables, $\mathbf{X}$, PLS computes the scores and loadings in such a way to describe the covariance between $\mathbf{X}$ and a response variable or matrix, $\mathbf{Y}$. In this context, we have a matrix consisting of the percent cover of each plant species in each chamber, and the response variable is the $\mathrm{N}_{2} \mathrm{O}$ flux. PLS should perform better than PCA in situations where an infrequent species (contributing little to the variance in $\mathbf{X}$ ) is highly correlated with $\mathbf{Y}$. In PLS, such a component would automatically be present in the first component, but would be a minor component in PCA.

\section{Results}

Figure 1 shows the spatial distribution of $\mathrm{N}$ deposition in the dry and wet deposition treatments. Deposition of $\mathrm{NH}_{3}$ peaks at around $100 \mathrm{~kg} \mathrm{Nha}^{-1} \mathrm{yr}^{-1}$, just downwind of the fumigation source. $\mathrm{NH}_{3}$ deposition decreases with downwind and cross-wind distance from the fumigation source, and approximates a Gaussian plume pattern expected from micrometeorological theory. The plume is aligned slightly to the east of 

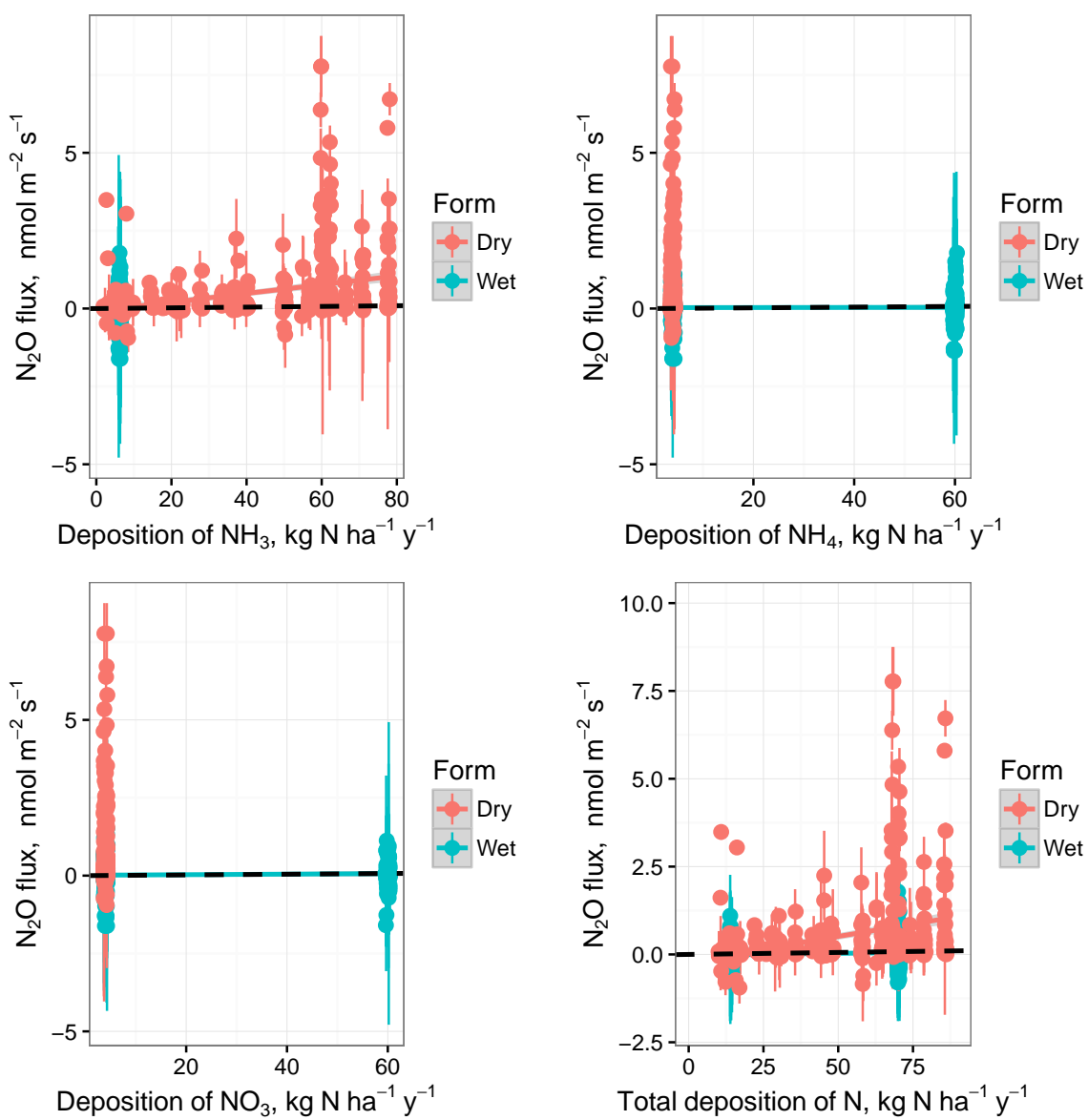

Figure 3. Response of $\mathrm{N}_{2} \mathrm{O}$ flux to deposition of $\mathrm{NH}_{3}, \mathrm{NH}_{4}^{+}, \mathrm{NO}_{3}^{-}$, and total $\mathrm{N}$ deposition. Error bars show the $95 \%$ confidence interval, based on the regression slope for each flux measurement. Solid lines show the fitted response from the general additive mixed model. Dotted lines show the emission predicted with the IPCC default emission factor, as $1 \%$ of the deposited N.

the boardwalk transect, although there is some uncertainty in the interpolation between $\mathrm{NH}_{3}$ samplers. Deposition of $\mathrm{NH}_{4}^{+}$ and $\mathrm{NO}_{3}^{-}$on the wet deposition plots are shown on the same colour scale. These are known with much greater certainty, as no modelling step is required.

Figure 2 shows the time series of nitrogen deposition in the $\mathrm{NH}_{4}^{+}$and $\mathrm{NO}_{3}^{-}$treatments, and on the $\mathrm{NH}_{3}$ transect at $16 \mathrm{~m}$, where annual deposition was similar to that in the $\mathrm{NH}_{4}^{+}$ and $\mathrm{NO}_{3}^{-}$treatments. Distribution of deposition events over time is similar in both treatments. Deposition events were spread over most days of the year, with no deposition only in a short period in mid-winter. $\mathrm{NH}_{3}$ deposition is calculated as a function of stomatal conductance (Cape et al., 2008), so rates are higher in daytime and in the summer.

Whilst there is considerable scatter in the response of $\mathrm{N}_{2} \mathrm{O}$ fluxes to mean annual nitrogen deposition, an increase in $\mathrm{N}_{2} \mathrm{O}$ flux with $\mathrm{NH}_{3}$ deposition was apparent (Fig. 3). No trend with $\mathrm{NH}_{4}^{+}$or $\mathrm{NO}_{3}^{-}$deposition was obvious. In many of the flux measurements, the magnitude of $\mathrm{N}_{2} \mathrm{O}$ fluxes was close to the measurement error in the static chamber method. In both the $\mathrm{NH}_{4}^{+}$and $\mathrm{NO}_{3}^{-}$treatments, only $9 \%$ of fluxes (re- spectively) had $95 \%$ confidence limits which did not include zero. Detecting a clear response is inevitably difficult when measurement noise contributes substantially to the variability in the data. By contrast, in the $\mathrm{NH}_{3}$ treatment, $40 \%$ of fluxes had confidence limits which did not include zero.

The output from the linear mixed model analysis is shown in Table 1, with the coefficients representing the response to the fixed factors. As well as showing significant responses to temperature and water table depth, $\mathrm{N}_{2} \mathrm{O}$ fluxes responded to $\mathrm{NH}_{3}$ deposition (Fig. 3). This response was greater than the default $1 \%$ IPCC emission factor, and comes close to $8.5 \%$ (with the appropriate unit conversion). The relationship may not be linear (Philibert et al., 2012), and the general additive mixed model (GAMM) was fitted to allow for non-linearity in the fixed effects. However, the exact form of the response to $\mathrm{NH}_{3}$ deposition was not well constrained by the data, especially at the lower values, and a simple linear fit was justified (Fig. 4). The modelled effect of $\mathrm{NH}_{4}^{+}$and $\mathrm{NO}_{3}^{-}$deposition was slightly negative on average, although positive and negative slopes are both plausible (Table 1, Fig. 4). 


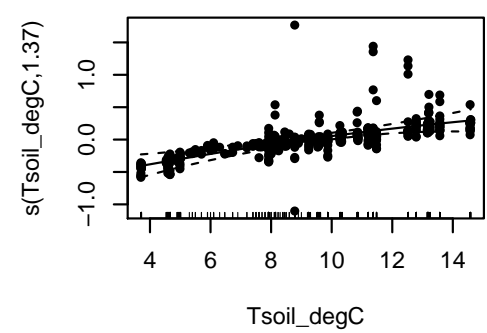

Fnh4

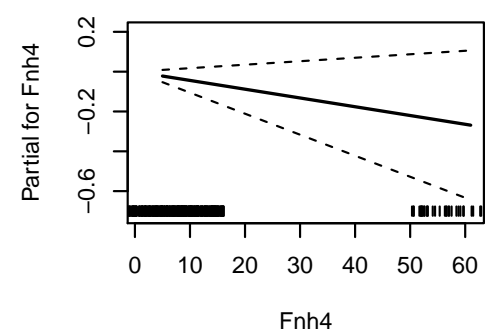

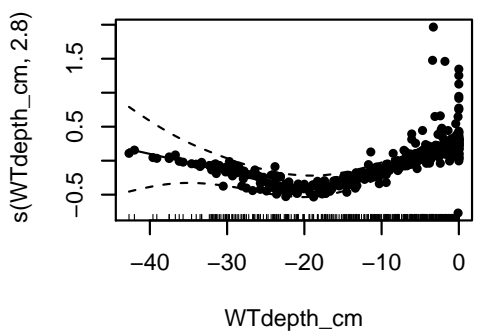

Fno3

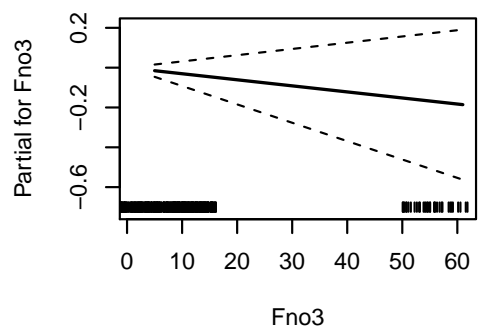

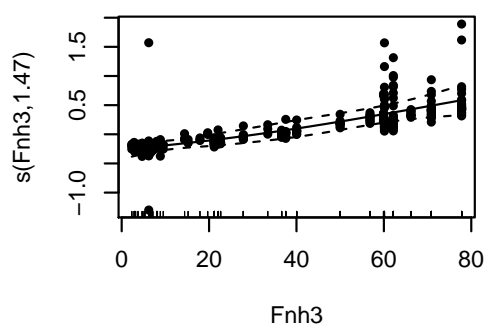

Figure 4. Fitted response of $\mathrm{N}_{2} \mathrm{O}$ flux to soil temperature, water table height, and deposition of $\mathrm{NH}_{3}, \mathrm{NH}_{4}^{+}$, and $\mathrm{NO}_{3}^{-}$, as estimated by the general additive mixed model. Partial residuals are shown for the smooth terms, which are the residuals that would be obtained by dropping the term concerned from the model, while leaving all other estimates fixed. $\mathrm{NH}_{4}^{+}$and $\mathrm{NO}_{3}^{-}$were treated as linear terms. Upper and lower lines show 2 standard errors above and below the fitted estimate.

Table 1. Results of fitting the linear mixed-effects model (Eq. 2) to the data by maximising the restricted log-likelihood. Columns show the denominator degrees of freedom, $F$ values, $p$ values from Wald tests for each term, and the $\beta$ coefficients in Eq. (2).

\begin{tabular}{lrrrr}
\hline & DF & $F$ value & $p$ value & Coefficient \\
\hline Intercept & 392 & 23.90 & 0.000 & -0.1664 \\
$T_{\text {soil }}$ & 392 & 16.75 & 0.000 & 0.0181 \\
$z_{\text {water }}$ & 392 & 22.81 & 0.000 & 0.0528 \\
$F_{\mathrm{NH}_{3}}$ & 40 & 29.96 & 0.000 & 0.0092 \\
$F_{\mathrm{NH}_{4}}$ & 40 & 1.27 & 0.267 & -0.0046 \\
$F_{\mathrm{NO}_{3}}$ & 40 & 1.74 & 0.194 & -0.0041 \\
\hline
\end{tabular}

$\mathrm{NH}_{4}^{+}$concentrations in the soil water were elevated in the high $\mathrm{NH}_{4}^{+}$deposition treatment, by around $1 \mathrm{mg} \mathrm{N} \mathrm{dm}^{-3}$ on average (Fig. 5). By contrast, the high $\mathrm{NO}_{3}^{-}$deposition treatment had no clear effect on $\mathrm{NO}_{3}^{-}$concentrations in the soil water. On the $\mathrm{NH}_{3}$ deposition transect, there was a clear trend in soil water concentrations of both $\mathrm{NH}_{4}^{+}$and $\mathrm{NO}_{3}^{-}$with $\mathrm{NH}_{3}$ deposition (Fig. 5, right-hand plots). At the equivalent level of $\mathrm{NH}_{3}$ deposition, $\mathrm{NH}_{4}^{+}$concentrations in the soil water were elevated by a similar amount to that in the high $\mathrm{NH}_{4}^{+}$ deposition treatment. There were weak relationships between $\mathrm{N}_{2} \mathrm{O}$ flux and $\mathrm{NH}_{4}^{+}$and $\mathrm{NO}_{3}^{-}$concentrations in the dry treatment, but no clear relationship in the wet treatment.

Vegetation composition provided reasonably good explanatory power for $\mathrm{N}_{2} \mathrm{O}$ flux, and the PLS regression explained $56 \%$ of the variance in $\mathrm{N}_{2} \mathrm{O}$ flux (Fig. 6). The first two components explained $27 \%$ of the variance, and gave an interpretable ordination of the chambers (Fig. 7). The chambers high on the first axis were dominated by Eriophorum vaginatum, often damaged by $\mathrm{NH}_{3}$, with little or no moss cover, and had high fluxes. The chambers low on the first axis had high cover of Sphagnum capillifolium and low fluxes. The second axis differentiates hummock and hollow vegetation, and a soil moisture difference. The drier hummocks with Calluna vulgaris and Deschampsia flexuosa had lower fluxes than the hollows.

\section{Discussion}

Our results confirm the early findings of Sheppard et al. (2013) that there was no clear response of $\mathrm{N}_{2} \mathrm{O}$ flux to deposition of $\mathrm{NH}_{4}^{+}$or $\mathrm{NO}_{3}^{-}$, whereas high doses of $\mathrm{NH}_{3}$ reduced the cover of Calluna vulgaris and Sphagnum species, and increased $\mathrm{N}_{2} \mathrm{O}$ flux. Other results in the literature show a range of responses of $\mathrm{N}_{2} \mathrm{O}$ emission to experimental $\mathrm{N}$ addition, from no response to substantial increases. Lund et al. (2009) found no effect of experimental $\mathrm{N}$ addition $\left(\mathrm{NH}_{4} \mathrm{NO}_{3}\right)$ on $\mathrm{N}_{2} \mathrm{O}$ emissions from two Swedish bogs, and peak fluxes were less than $1 \mathrm{nmol} \mathrm{m}^{-2} \mathrm{~s}^{-1}$, when $40 \mathrm{~kg} \mathrm{Nha}^{-1} \mathrm{yr}^{-1}$ was applied in only three relatively large doses. Nykanen et al. (2002) found no response of $\mathrm{N}_{2} \mathrm{O}$ emission to additions of up to $100 \mathrm{~kg} \mathrm{Nha}^{-1} \mathrm{yr}^{-1}\left(\mathrm{NH}_{4} \mathrm{NO}_{3}\right)$ to a Sphagnum fuscum pine bog in Finland, over a 6-year study. Following nitrate addition to ex situ peat cores from Polish sedge fen, Roobroeck et al. (2010) observed no increase in $\mathrm{N}_{2} \mathrm{O}$ emissions 

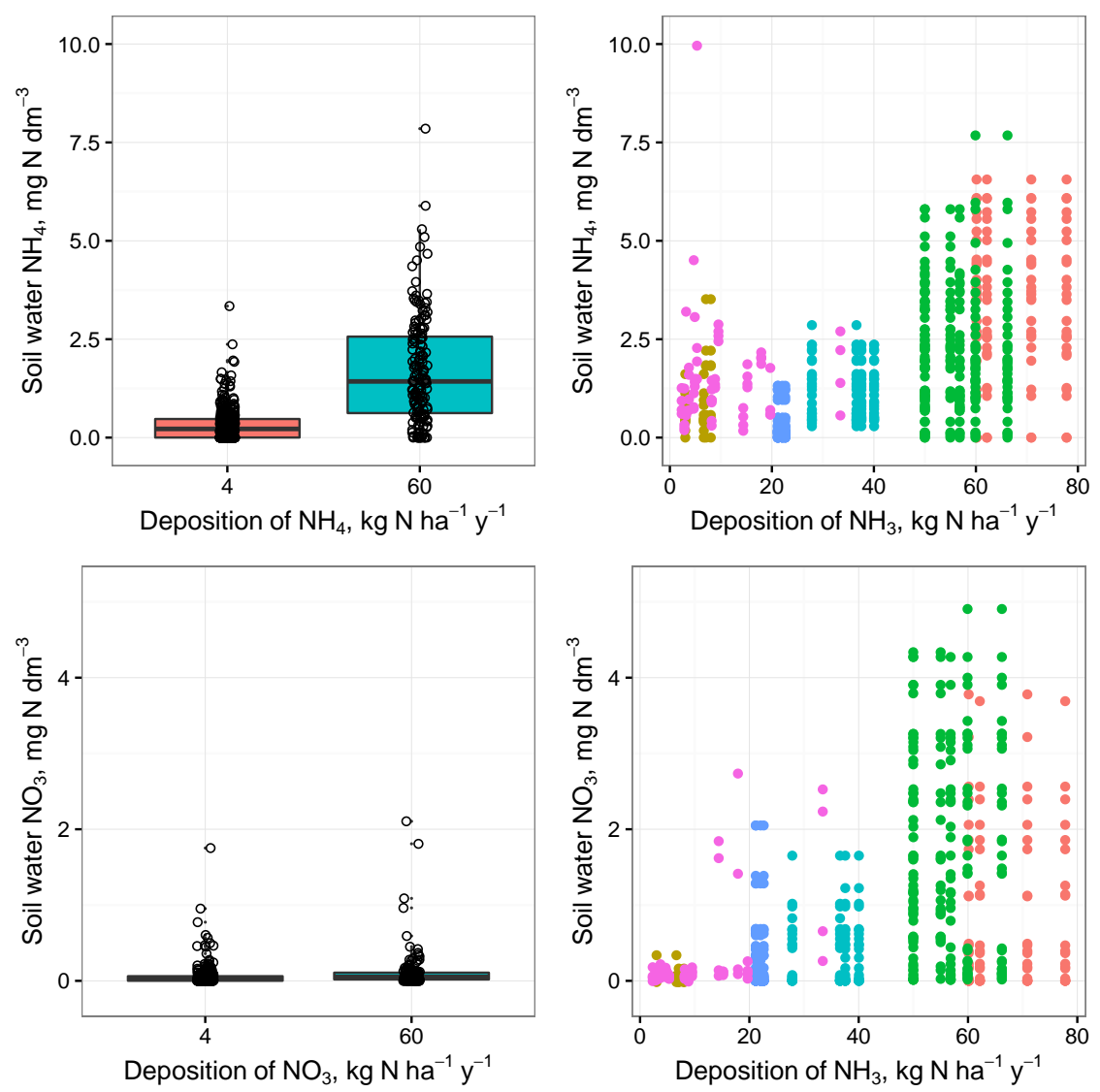

Figure 5. $\mathrm{NH}_{4}^{+}$and $\mathrm{NO}_{3}^{-}$concentrations in the soil water in the experimental treatments. In the right-hand plots, colours show measurements grouped by distances downwind of the fumigation source.

from cores from vegetated tussocks or unvegetated hollows, except for an increase of $0.15 \mathrm{nmol} \mathrm{m}^{-2} \mathrm{~s}^{-1}$ at their low nitrate $\left(\mathrm{KNO}_{3}\right)$ addition rate.

Some clearer positive responses have been observed where bogs have been drained, or where very high levels of nitrogen have been applied. Regina et al. (1998) found that $\mathrm{N}_{2} \mathrm{O}$ emissions were increased by up to $0.8 \mathrm{nmol} \mathrm{m}^{-2} \mathrm{~s}^{-1}$ for around nine months after a single experimental $\mathrm{N}$ addition of $100 \mathrm{~kg} \mathrm{Nha}^{-1} \mathrm{yr}^{-1}$ on a drained and forested peatland in Finland; $\mathrm{KNO}_{3}, \mathrm{NH}_{4} \mathrm{Cl}$, and urea gave a similar range of responses. Zhang et al. (2007) observed an increase of $0.3 \mathrm{nmol} \mathrm{m}^{-2} \mathrm{~s}^{-1}$ with the application of $240 \mathrm{~kg} \mathrm{~N} \mathrm{ha}^{-1} \mathrm{yr}^{-1}$ $\left(\mathrm{NH}_{4} \mathrm{NO}_{3}\right)$ to a freshwater marsh in China, bi-weekly over the summer growing season. Clear responses can, however, be very short-lived. For example, Gao et al. $(2014,2015)$ found a short-term response of $\mathrm{N}_{2} \mathrm{O}$ efflux to $\mathrm{NH}_{4} \mathrm{NO}_{3}$ addition in an in vivo study of soil from an alpine peatland in Tibet, but differences from the control lasted less than 10 days.

A response of $\mathrm{N}_{2} \mathrm{O}$ emissions to nitrogen addition is more often detectable in laboratory incubations, where there are fewer feedbacks and interactions. Field studies commonly show complex interactions with other variables, resulting in no effect in the field, or making interpretation of results com- plicated. In a Finnish spruce swamp buffer zone, Saari et al. (2013) found that nitrogen addition increased $\mathrm{N}_{2} \mathrm{O}$ efflux in laboratory incubations, but in situ $\mathrm{N}_{2} \mathrm{O}$ effluxes were low and unresponsive. Regina et al. (1996) found that $\mathrm{N}_{2} \mathrm{O}$ fluxes were positively correlated with the numbers of nitrite oxidisers, nitrification potential, $\mathrm{N}, \mathrm{P}, \mathrm{Ca}$, and $\mathrm{pH}$ of the soil and negatively correlated with the level of the water table and $\mathrm{K}$ content of the soil. In a study by Silvan et al. (2005) on a restored peatland in Finland, $\mathrm{N}_{2} \mathrm{O}$ emissions showed an asymptotic increase with nitrate concentration, and an exponential decrease with $E$. vaginatum cover. The interpretation was that $\mathrm{N}_{2} \mathrm{O}$ emission was the outcome of resource competition for nitrate between denitrifying bacteria and (E. vaginatum) roots, but both have limited capacities for uptake of nitrate.

We can interpret our results similarly in terms of resource competition for nitrate. The wet deposition of $\mathrm{NO}_{3}^{-}$did not increase concentrations of $\mathrm{NO}_{3}^{-}$in the soil water. Previous data suggest that all the additional $\mathrm{N}$ deposited on the wet treatment plots accumulated in the top $10 \mathrm{~cm}$ of the peat and below-ground vegetation (based on the accumulation of $\mathrm{N}$ in the different pools shown in Sheppard et al. (2013), Fig. 7, although estimates are rather uncertain because of sensitivity to 


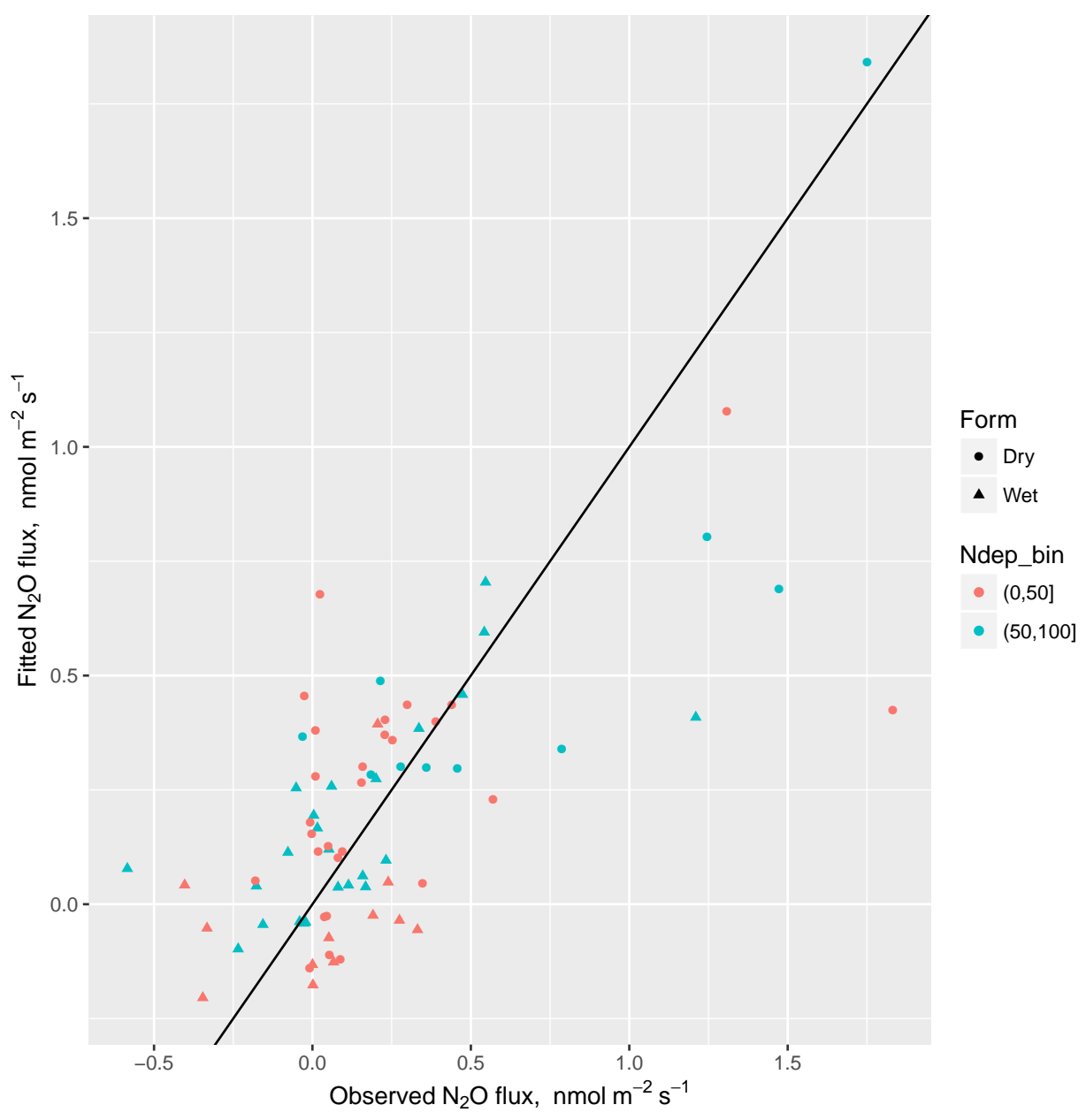

Figure 6. Mean $\mathrm{N}_{2} \mathrm{O}$ flux at each chamber location fitted by the PLS model based on vegetation species composition plotted against observed mean fluxes. The data are grouped by nitrogen treatment form (symbol shape) and dose (symbol colour). The solid line shows the $1: 1$ line.

errors in bulk density, $\mathrm{C}$ and $\mathrm{N}$ concentrations, and sampling error). The deposited nitrogen was thereby immobilised, and not available to soil microbes, and was not denitrified to $\mathrm{N}_{2} \mathrm{O}$. The wet deposition of $\mathrm{NH}_{4}^{+}$did increase concentrations of $\mathrm{NH}_{4}^{+}$in the soil water, but $\mathrm{NH}_{4}^{+}$is less directly related to the microbial production of $\mathrm{N}_{2} \mathrm{O}$. In the dry deposition treatment at high levels of $\mathrm{NH}_{3}$ deposition, although there was similar accumulation of the deposited $\mathrm{N}$ in the peat, much of the vegetation cover was killed, leaving only a sparse cover dominated by $E$. vaginatum. The deposited $\mathrm{N}$ was therefore more available to soil microbes because there was less competition with plants, and could be denitrified to $\mathrm{N}_{2} \mathrm{O}$.

One of the difficulties in interpreting these results is that there are multiple microbial processes occurring (nitrification, denitrification, and $\mathrm{N}_{2} \mathrm{O}$ consumption), but the chamber flux measurements only give the net exchange of $\mathrm{N}_{2} \mathrm{O}$. The treatments could affect these multiple processes in different ways, e.g. via their effects on $\mathrm{pH}$ (and thereby influencing the microbial populations), or more directly by altering the amount of substrate for denitrification. However, without detailed information on the nitrification and denitrification potentials, it is difficult to draw stronger conclusions. Some studies have suggested that gross uptake of $\mathrm{N}_{2} \mathrm{O}$ can be substantial, at least in forest soils (Chapuis-Lardy et al., 2007; Frasier et al., 2010). In our study, the negative fluxes are so small compared to the measurement error, that no real pattern can be discerned, and this is a common finding in agricultural systems (Cowan et al., 2014b).

The multivariate analysis of the vegetation provided the best means for explaining the variation in $\mathrm{N}_{2} \mathrm{O}$ fluxes. Shifts in the species composition appeared to be the clearest sign that $\mathrm{N}$ deposition was affecting the long-term outcome of resource competition for nitrate, and thereby influencing $\mathrm{N}_{2} \mathrm{O}$ flux. A similar result was found in a multivariate analysis of vegetation in relation to methane flux in the UK ecosystems (Levy et al., 2012; Gray et al., 2013). Direct relationships between $\mathrm{N}_{2} \mathrm{O}$ flux and both nitrate and ammonium were poor, possibly because these are influenced by feedback from the flux itself. 


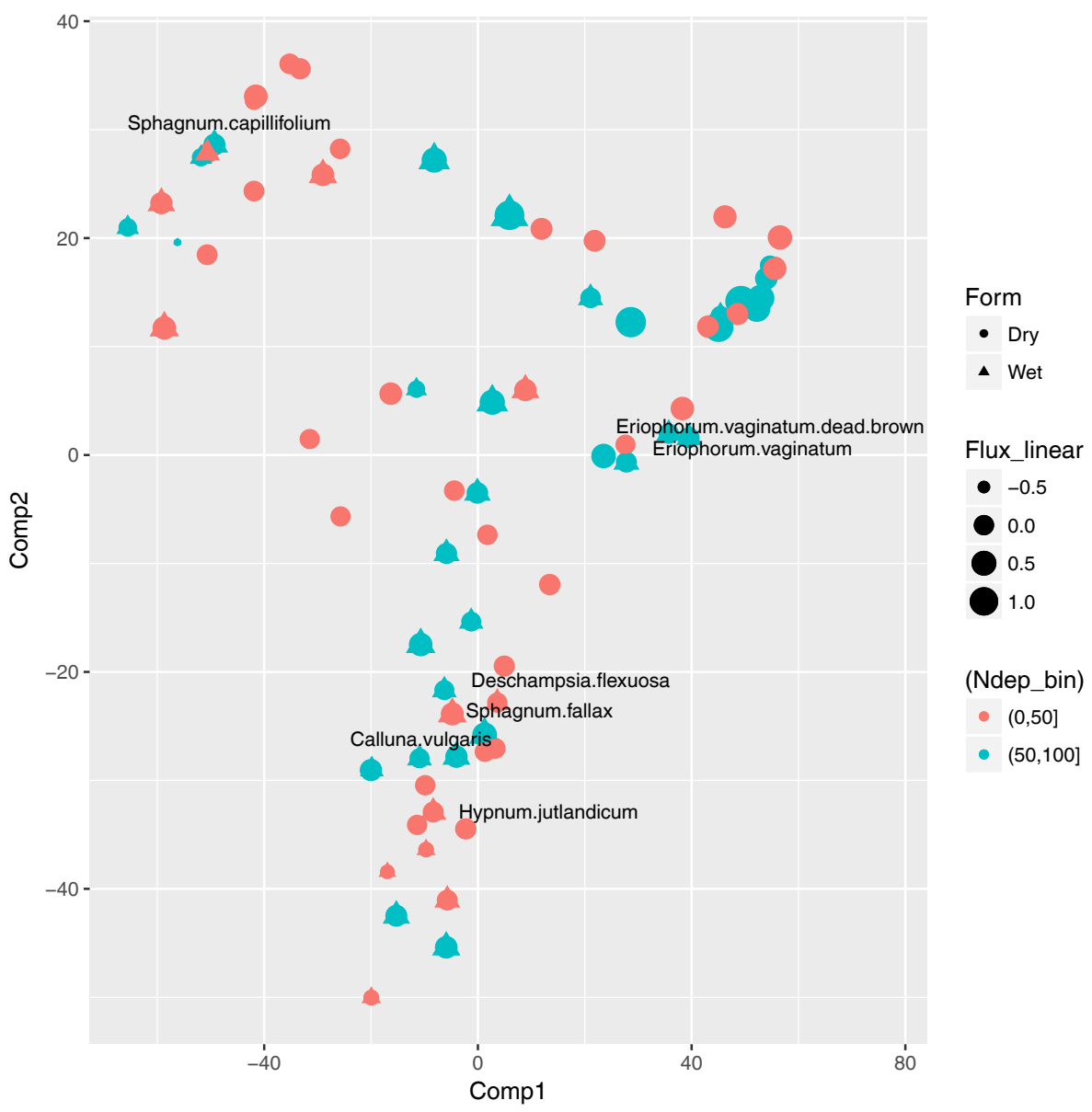

Figure 7. Biplot showing the scores for each chamber location for the first two PLS components. The first two PLS components represent the orthogonal indices of vegetation species composition which are the best linear predictors of mean $\mathrm{N}_{2} \mathrm{O}$ flux at each chamber location. The loadings for the important plant species are superimposed, indicating which species contribute most to the components. The data are grouped by nitrogen treatment form (symbol shape) and dose (symbol colour); symbol size is proportional to the magnitude of the mean $\mathrm{N}_{2} \mathrm{O}$ flux.

The unique aspect of the experimental design, in providing a very realistic simulation of nitrogen deposition rates, in terms of frequency and exposure concentrations, makes detecting effects more difficult. Unlike measuring $\mathrm{N}_{2} \mathrm{O}$ fluxes on agricultural land, where large peak emissions typically follow fertiliser applications, here we are measuring small, diffuse $\mathrm{N}_{2} \mathrm{O}$ fluxes spread over the whole year, which is necessarily more difficult.

Experimental designs of the wet and dry deposition experiments were quite different, because of the logistics of applying gases and liquids to ecosystems. This may partly explain why the effect of $\mathrm{NH}_{3}$ was easier to detect. $\mathrm{NH}_{3}$ was applied on a larger spatial scale, with very high rates of deposition adjacent to the fumigation outlet. Implicitly, we assume that differences with distance are effects of $\mathrm{NH}_{3}$, as there was no true replication (i.e. there was only one transect). Given this assumption, we take $n$ to be 60 in the $\mathrm{NH}_{3}$ experiment. The probability of detecting an effect size of $+0.068 \mathrm{nmol} \mathrm{m}^{-2} \mathrm{~s}^{-1}\left(=1 \%\right.$ of $\left.60 \mathrm{~kg} \mathrm{Nha}^{-1} \mathrm{yr}^{-1}\right)$ is rea- sonably high ( $p=0.96)$, from a standard power analysis (Cohen, 1988), given the typical measurement error in static chamber data (and ignoring between-plot variability). In the case of the wet deposition experiment, there were true replicate plots in a randomised block design, but sample size was small (4 plots per treatment). The probability of detecting the same effect size with $n=4$ is rather low ( $p=0.13$ ).

In our experimental results, neither $\mathrm{NH}_{4}^{+}$nor $\mathrm{NO}_{3}^{-}$deposition increased fluxes of $\mathrm{N}_{2} \mathrm{O}$ (indeed the mean effect of both was negative), and all the deposited $\mathrm{N}$ appeared to be retained in the peat and below-ground vegetation. However, we need to be careful before concluding that the true effect was zero (or negative), given that the effect size we were looking for was small. An emission factor of $1 \%$ is not inconsistent with the data, given the between-plot variability, measurement precision and small sample size. If this were the true emission factor, we can estimate the $\mathrm{N}_{2} \mathrm{O}$ emission resulting from $\mathrm{N}$ deposition over peatlands in the UK. Combined deposition rates of $\mathrm{NH}_{4}^{+}$and $\mathrm{NO}_{3}^{-}$are generally less than 
$10 \mathrm{~kg} \mathrm{~N} \mathrm{ha}^{-1} \mathrm{yr}^{-1}$ on UK peatbogs (Department for Environment, Food and Rural Affairs, 2016). With a $1 \%$ emission factor, this would imply a mean emission of $11 \mathrm{pmol} \mathrm{m}^{-2} \mathrm{~s}^{-1}$ or $1.3 \mathrm{~g} \mathrm{C}_{-} \mathrm{CO}_{2}$ eq. $\mathrm{m}^{-2} \mathrm{yr}^{-1}$. (To express $\mathrm{N}_{2} \mathrm{O}$ flux in units of $\mathrm{C}-\mathrm{CO}_{2}$ equivalents, we convert to a mass of $\mathrm{N}_{2} \mathrm{O}$ and multiply by 298 (the global warming potential of $\mathrm{N}_{2} \mathrm{O}$ over a 100 year time period including carbon cycle feedbacks, IPCC, 2013) and report only the mass of carbon in the $\mathrm{CO}_{2}$ equivalents, i.e. 12/44.) This compares with contemporary net ecosystem carbon balance measurements in the range of $28-50 \mathrm{~g} \mathrm{C}-\mathrm{CO}_{2}$ eq. $\mathrm{m}^{-2} \mathrm{yr}^{-1}$ in UK peatlands (Helfter et al., 2014; Levy and Gray, 2015).

$\mathrm{NH}_{3}$ has a different spatial distribution, being deposited much closer to its sources, so with high "hotspots", but with lower overall mean deposition rates $\left(<5 \mathrm{~kg} \mathrm{Nha}^{-1} \mathrm{yr}^{-1}\right)$. In the immediate vicinity of a large agricultural source, high mean emissions of $\mathrm{N}_{2} \mathrm{O}$ would be predicted, in the order of $0.58 \mathrm{nmol} \mathrm{m}^{-2} \mathrm{~s}^{-1}$ or $65 \mathrm{~g} \mathrm{C}^{-\mathrm{CO}_{2}}$ eq. $\mathrm{m}^{-2} \mathrm{yr}^{-1}$ (i.e. $8.5 \%$ of $60 \mathrm{~kg} \mathrm{Nha}^{-1} \mathrm{yr}^{-1}$ ), but over relatively small areas. This approaches the large values observed by Repo et al. (2009) in Arctic bare peat circles (averaging $0.86 \mathrm{nmol} \mathrm{m}^{-2} \mathrm{~s}^{-1}$ or $97 \mathrm{~g} \mathrm{C}^{-\mathrm{CO}_{2}}$ eq. $\mathrm{m}^{-2} \mathrm{yr}^{-1}$ ), but upscaling these emissions to national scale is challenging.

Data availability. The dataset used in this article is available at https://doi.org/10.5285/7c1dd26a-5df5-4b90-854b-70d0d97eb78a (Levy and Leeson, 2017).

Author contributions. LJS and MAS designed the experiment. SRL, MRJ, and LJS maintained the experiment. SRL collected the bulk of the flux data, with additional data collected by JD, SR, JK, and IW. NvD collected vegetation data and analysed the soil chemistry data. PEL performed the statistical analysis and wrote the manuscript.

Competing interests. The authors declare that they have no conflict of interest.

Acknowledgements. The project was funded by the UK Natural Environment Council GANE programme, the EU FP6 project NitroEurope, and the EU FP7 project ECLAIRE.

Edited by: Xinming Wang

Reviewed by: Dejun Li and Tim Moore

\section{References}

Bobbink, R., Hornung, M., and Roelofs, J.: The Effects of AirBorne Nitrogen Pollutants on Species Diversity in Natural and Semi-Natural European Vegetation, J. Ecol., 86, 717-738, https://doi.org/10.1046/j.1365-2745.1998.8650717.x, 1998.
Cape, J., Jones, M., Leith, I., Sheppard, L., van Dijk, N., Sutton, M., and Fowler, D.: Estimate of Annual $\mathrm{NH}_{3}$ Dry Deposition to a Fumigated Ombrotrophic Bog Using ConcentrationDependent Deposition Velocities, Atmos. Environ., 42, 66376646, https://doi.org/10.1016/j.atmosenv.2008.04.027, 2008.

Chapuis-Lardy, L., Wrage, N., Metay, A., Chotte, J.-L., and Bernoux, M.: Soils, a Sink for $\mathrm{N}_{2} \mathrm{O}$ ? A Review, Glob. Change Biol., 13, 1-17, https://doi.org/10.1111/j.13652486.2006.01280.x, 2007.

Cohen, J.: Statistical Power Analysis for the Behavioral Sciences, L. Erlbaum Associates, Hillsdale, N.J., 400 pp., ISBN-13: 9780-8058-0283-2, 1988.

Cowan, N. J., Famulari, D., Levy, P. E., Anderson, M., Bell, M. J., Rees, R. M., Reay, D. S., and Skiba, U. M.: An Improved Method for Measuring Soil $\mathrm{N}_{2} \mathrm{O}$ Fluxes Using a Quantum Cascade Laser with a Dynamic Chamber: Dynamic Chamber Method, Eur. J. Soil Sci., 65, 643-652, https://doi.org/10.1111/ejss.12168, 2014a.

Cowan, N. J., Famulari, D., Levy, P. E., Anderson, M., Reay, D. S., and Skiba, U. M.: Investigating uptake of $\mathrm{N}_{2} \mathrm{O}$ in agricultural soils using a high-precision dynamic chamber method, Atmos. Meas. Tech., 7, 4455-4462, https://doi.org/10.5194/amt-7-44552014, 2014b.

Curtis, C., Emmett, B., Grant, H., Kernan, M., Reynolds, B., and Shilland, E.: Nitrogen Saturation in UK Moorlands: The Critical Role of Bryophytes and Lichens in Determining Retention of Atmospheric N Deposition, J. Appl. Ecol., 42, 507-517, https://doi.org/10.1111/j.1365-2664.2005.01029.x, 2005.

De Klein, $\mathrm{C} .: \mathrm{N}_{2} \mathrm{O}$ Emissions from Managed Soils, and $\mathrm{CO}_{2}$ Emissions from Lime and Urea Application, in: Volume 4 Agriculture, Forestry and Other Land Use, vol. 4 of IPCC Guidelines for National Greenhouse Gas Inventories, Intergovernmental Panel on Climate Change, Geneva, 2006.

Department for Environment, Food and Rural Affairs: UK Deposition Data, available at: http://pollutantdeposition.defra.gov.uk/ data, last access: 1 June 2016.

Fowler, D., O’Donoghue, M., Muller, J. B. A., Smith, R. I., Dragosits, U., Skiba, U., Sutton, M. A., and Brimblecombe, P.: A Chronology of Nitrogen Deposition in the UK between 1900 and 2000, Water Air Soil Poll.: Focus, 4, 9-23, https://doi.org/10.1007/s11267-005-3009-9, 2005.

Frasier, R., Ullah, S., and Moore, T. R.: Nitrous Oxide Consumption Potentials of Well-Drained Forest Soils in Southern Québec, Canada, Geomicrobiol. J., 27, 53-60, https://doi.org/10.1080/01490450903232199, 2010.

Gao, Y., Chen, H., and Zeng, X.: Effects of Nitrogen and Sulfur Deposition on $\mathrm{CH}_{4}$ and $\mathrm{N}_{2} \mathrm{O}$ Fluxes in HighAltitude Peatland Soil under Different Water Tables in the Tibetan Plateau, Soil Sci. Plant Nutr., 60, 404-410, https://doi.org/10.1080/00380768.2014.893812, 2014.

Gao, Y., Chen, H., Schumann, M., Wu, Y., and Zeng, X.: ShortTerm Responses Of Nitrous Oxide Fluxes To Nitrogen And Phosphorus Addition In A Peatland On The Tibetan Plateau, Environ. Eng. Manag. J., 14, 121-127, 2015.

Gray, A., Levy, P. E., Cooper, M. D. A., Jones, T., Gaiawyn, J., Leeson, S. R., Ward, S. E., Dinsmore, K. J., Drewer, J., Sheppard, L. J., Ostle, N. J., Evans, C. D., Burden, A., and Zieliński, P.: Methane Indicator Values for Peatlands: A Comparison of 
Species and Functional Groups, Glob. Change Biol., 19, 11411150, https://doi.org/10.1111/gcb.12120, 2013.

Helfter, C., Campbell, C., Dinsmore, K. J., Drewer, J., Coyle, M., Anderson, M., Skiba, U., Nemitz, E., Billett, M. F., and Sutton, M. A.: Drivers of long-term variability in $\mathrm{CO}_{2}$ net ecosystem exchange in a temperate peatland, Biogeosciences, 12, 1799-1811, https://doi.org/10.5194/bg-12-1799-2015, 2015.

Hutchinson, G. L. and Mosier, A. R.: Improved Soil Cover Method for Field Measurement of Nitrous Oxide Fluxes1, Soil Sci. Soc. Am. J., 45, 311, https://doi.org/10.2136/sssaj1981.03615995004500020017x, 1981.

IPCC: Climate Change 2013: The Physical Science Basis. Contribution of Working Group I to the Fifth Assessment Report of the Intergovernmental Panel on Climate Change, Cambridge University Press, Cambridge, United Kingdom and New York, NY, USA, 2013.

Juutinen, S., Bubier, J. L., and Moore, T. R.: Responses of Vegetation and Ecosystem $\mathrm{CO}_{2}$ Exchange to 9 Years of Nutrient Addition at Mer Bleue Bog, Ecosystems, 13, 874-887, https://doi.org/10.1007/s10021-010-9361-2, 2010.

Lamers, L., Bobbink, R., and Roelofs, J.: Natural Nitrogen Filter Fails in Polluted Raised Bogs, Glob. Change Biol., 6, 583-586, https://doi.org/10.1046/j.1365-2486.2000.00342.x, 2000.

Leith, I. D., Sheppard, L. J., Fowler, D., Cape, J. N., Jones, M., Crossley, A., Hargreaves, K. J., Tang, Y. S., Theobald, M., and Sutton, M. R.: Quantifying Dry $\mathrm{NH}_{3}$ Deposition to an Ombrotrophic Bog from an Automated NH3 Field Release System, Water, Air, \& Soil Poll.: Focus, 4, 207-218, https://doi.org/10.1007/s11267-004-3031-3, 2004.

Levy, P. E. and Gray, A.: Greenhouse Gas Balance of a SemiNatural Peatbog in Northern Scotland, Environ. Res. Lett., 10, 094019, https://doi.org/10.1088/1748-9326/10/9/094019, 2015.

Levy, P. E. and Leeson, S. R.: Nitrous oxide emissions from Whim peatbog after thirteen years of experimental nitrogen deposition, Dataset, https://doi.org/10.5285/7c1dd26a-5df5-4b90854b-70d0d97eb78a, 2017.

Levy, P. E., Gray, A., Leeson, S. R., Gaiawyn, J., Kelly, M. P. C., Cooper, M. D. A., Dinsmore, K. J., Jones, S. K., and Sheppard, L. J.: Quantification of Uncertainty in Trace Gas Fluxes Measured by the Static Chamber Method, Eur. J. Soil Sci., 62, 811821, https://doi.org/10.1111/j.1365-2389.2011.01403.x, 2011.

Levy, P. E., Burden, A., Cooper, M. D. A., Dinsmore, K. J., Drewer, J., Evans, C., Fowler, D., Gaiawyn, J., Gray, A., Jones, S. K., Jones, T., McNamara, N. P., Mills, R., Ostle, N., Sheppard, L. J., Skiba, U., Sowerby, A., Ward, S. E., and Zieliński, P.: Methane Emissions from Soils: Synthesis and Analysis of a Large UK Data Set, Glob. Change Biol., 18, 1657-1669, https://doi.org/10.1111/j.1365-2486.2011.02616.x, 2012.

Lund, M., Christensen, T. R., Mastepanov, M., Lindroth, A., and Ström, L.: Effects of $\mathrm{N}$ and $\mathrm{P}$ fertilization on the greenhouse gas exchange in two northern peatlands with contrasting $\mathrm{N}$ deposition rates, Biogeosciences, 6, 2135-2144, https://doi.org/10.5194/bg-6-2135-2009, 2009.

Mevik, B.-H. and Wehrens, R.: The Pls Package: Principal Component and Partial Least Squares Regression in R, J. Stat. Softw., $18,1-24,2007$

Nicol, G. W., Leininger, S., Schleper, C., and Prosser, J. I.: The Influence of Soil $\mathrm{pH}$ on the Diversity, Abundance and Transcriptional Activity of Ammonia Oxidizing Archaea and Bacteria, Environmen. Microbiol., 10, 2966-2978, https://doi.org/10.1111/j.1462-2920.2008.01701.x, 2008.

Nykanen, H., Vasander, H., Huttunen, J. T., and Martikainen, P. J.: Effect of Experimental Nitrogen Load on Methane and Nitrous Oxide Fluxes on Ombrotrophic Boreal Peatland, Plant Soil, 242, 147-155, https://doi.org/10.1023/A:1019658428402, 2002.

Philibert, A., Loyce, C., and Makowski, D.: Quantifying Uncertainties in $\mathrm{N}_{2} \mathrm{O}$ Emission Due to $\mathrm{N}$ Fertilizer Application in Cultivated Areas, PLoS ONE, 7, e50950, https://doi.org/10.1371/journal.pone.0050950, 2012.

Pinheiro, J. and Bates, D.: Mixed-Effects Models in S and S-PLUS, Springer Science \& Business Media, New York, NY, 528 pp., ISBN-13: 978-0-387-98957-0, 2006.

Regina, K., Nykanen, H., Silvola, J., and Martikainen, P.: Fluxes of Nitrous Oxide from Boreal Peatlands as Affected by Peatland Type, Water Table Level and Nitrification Capacity, Biogeochemistry, 35, 401-418, https://doi.org/10.1007/BF02183033, 1996.

Regina, K., Nykänen, H., Maljanen, M., Silvola, J., and Martikainen, P. J.: Emissions of $\mathrm{N}_{2} \mathrm{O}$ and $\mathrm{NO}$ and Net Nitrogen Mineralization in a Boreal Forested Peatland Treated with Different Nitrogen Compounds, Can. J. Forest Res., 28, 132-140, https://doi.org/10.1139/x97-198, 1998.

Repo, M. E., Susiluoto, S., Lind, S. E., Jokinen, S., Elsakov, V., Biasi, C., Virtanen, T., and Martikainen, P. J.: Large $\mathrm{N}_{2} \mathrm{O}$ Emissions from Cryoturbated Peat Soil in Tundra, Nat. Geosci., 2, 189-192, https://doi.org/10.1038/ngeo434, 2009.

Rodwell, J. S.: British Plant Communities, Cambridge University Press, Cambridge, 30 pp., 1998.

Roobroeck, D., Butterbach-Bahl, K., Brüggemann, N., and Boeckx, P.: Dinitrogen and Nitrous Oxide Exchanges from an Undrained Monolith Fen: Short-Term Responses Following Nitrate Addition, Eur. J. Soil Sci., 61, 662-670, https://doi.org/10.1111/j.1365-2389.2010.01269.x, 2010.

Saari, P., Saarnio, S., Heinonen, J., and Alm, J.: Emissions and Dynamics of $\mathrm{N}_{2} \mathrm{O}$ in a Buffer Wetland Receiving Water Flows from a Forested Peatland, Boreal Environ. Res., 18, 164-180, 2013.

Sheppard, L. J., Crossley, A., Leith, I. D., Hargreaves, K. J., Carfrae, J. A., van Dijk, N., Cape, J. N., Sleep, D., Fowler, D., and Raven, J. A.: An Automated Wet Deposition System to Compare the Effects of Reduced and Oxidised N on Ombrotrophic Bog Species: Practical Considerations, Water, Air, \& Soil Poll.: Focus, 4, 197205, https://doi.org/10.1007/s11267-004-3030-4, 2004.

Sheppard, L. J., Leith, I. D., Crossley, A., Van Dijk, N., Fowler, D., Sutton, M. A., and Woods, C.: Stress Responses of Calluna Vulgaris to Reduced and Oxidised N Applied under 'real World Conditions', Environ. Pollut., 154, 404-413, https://doi.org/10.1016/j.envpol.2007.10.040, 2008.

Sheppard, L. J., Leith, I. D., Mizunuma, T., Neil Cape, J., Crossley, A., Leeson, S., Sutton, M. A., Dijk, N., and Fowler, D.: Dry Deposition of Ammonia Gas Drives Species Change Faster than Wet Deposition of Ammonium Ions: Evidence from a LongTerm Field Manipulation, Glob. Change Biol., 17, 3589-3607, https://doi.org/10.1111/j.1365-2486.2011.02478.x, 2011.

Sheppard, L. J., Leith, I. D., Leeson, S. R., van Dijk, N., Field, C., and Levy, P.: Fate of $\mathrm{N}$ in a peatland, Whim bog: immobilisation in the vegetation and peat, leakage into pore water and losses 
as $\mathrm{N}_{2} \mathrm{O}$ depend on the form of $\mathrm{N}$, Biogeosciences, 10, 149-160, https://doi.org/10.5194/bg-10-149-2013, 2013.

Sheppard, L. J., Leith, I. D., Mizunuma, T., Leeson, S., Kivimaki, S., Neil Cape, J., van Dijk, N., Leaver, D., Sutton, M. A., Fowler, D., Van den Berg, L. J., Crossley, A., Field, C., and Smart, S.: Inertia in an Ombrotrophic Bog Ecosystem in Response to 9 Years' Realistic Perturbation by Wet Deposition of Nitrogen, Separated by Form, Glob. Change Biol., 20, 566-580, https://doi.org/10.1111/gcb.12357, 2014.

Silvan, N., Tuittila, E. S., Kitunen, V., Vasander, H., and Laine, J.: Nitrate Uptake by Eriophorum Vaginatum Controls $\mathrm{N}_{2} \mathrm{O}$ Production in a Restored Peatland, Soil Biol. Biochem., 37, 1519-1526, https://doi.org/10.1016/j.soilbio.2005.01.006, 2005.

Simek, M. and Cooper, J.: The Influence of Soil pH on Denitrification: Progress towards the Understanding of This Interaction over the Last 50 Years, Eur. J. Soil Sci., 53, 345-354, https://doi.org/10.1046/j.1365-2389.2002.00461.x, 2002.
Tang, Y. S., Cape, J. N., and Sutton, M. A.: Development and Types of Passive Samplers for Monitoring Atmospheric $\mathrm{NO}_{2}$ and $\mathrm{NH}_{3}$ Concentrations, The Scientific World Journal, 1, 513-529, https://doi.org/10.1100/tsw.2001.82, 2001.

Wood, S. N.: Generalized Additive Models: An Introduction with R, Chapman and Hall/CRC, Boca Raton FL, 410 pp., ISBN-13: 978-1-5848-8474-3, 2006.

Zhang, L., Song, C., Zheng, X., Wang, D., and Wang, Y.: Effects of Nitrogen on the Ecosystem Respiration, $\mathrm{CH}_{4}$ and $\mathrm{N}_{2} \mathrm{O}$ Emissions to the Atmosphere from the Freshwater Marshes in Northeast China, Environmental Geology, 52, 529-539, https://doi.org/10.1007/s00254-006-0485-9, 2007. 